\title{
Population dynamics of the invasive Pacific oyster Crassostrea gigas during the early stages of an outbreak in the Wadden Sea (Germany)
}

\author{
Andreas Schmidt • Achim Wehrmann • \\ Sabine Dittmann
}

Received: 21 November 2007/Revised: 29 March 2008/ Accepted: 21 July 2008/Published online: 22 August 2008

(C) Springer-Verlag and AWI 2008

\begin{abstract}
Since the late 1990s, the Pacific oyster (Crassostrea gigas) has spread into the East Frisian Wadden Sea (Germany). This invasion provided an opportunity to study the population dynamics and the patterns of spread during the initial bioinvasion process. With its source area in The Netherlands, the bioinvasion continues in an eastward direction, as documented by a gradient of high abundances in the west and low abundances in the east during the first study year. One year later, abundances of the Pacific oyster were more heterogenic and differed between adjacent tidal basins. The increase in population sizes at all study sites was very high, reaching levels similar to native occurrence populations. The growth constant $(K)$ varied between 0.300 and 0.990 year $^{-1}$. The mussel bed with the highest densities had a mean abundance of $>300$ ind. $\mathrm{m}^{-2}$, and a maximum of 1,460 ind. $\mathrm{m}^{-2}$. Furthermore, the bioinvasion was facilitated by a low mortality $(Z)$ found for populations between 0.5 and 1.5 years old $\left(Z=0.03-0.13\right.$ year $\left.^{-1}\right)$. At present, Pacific oysters are well established at several locations in the East Frisian Wadden Sea and may become with these reproductive potential self-sustaining populations.
\end{abstract}

Communicated by K. Reise.

A. Schmidt $(\bowtie) \cdot$ A. Wehrmann

Senckenberg Institute, Südstrand 40,

26382 Wilhelmshaven, Germany

e-mail: andreas.schmidt@senckenberg.de

S. Dittmann

School of Biological Sciences,

Flinders University of South Australia,

GPO Box 2100, Adelaide, SA 5001, Australia
Keywords Bioinvasion - Population growth - Mortality · Larvae dispersal $\cdot$ Non-indigenous

\section{Introduction}

Biological invasions consist of human induced species translocation such as global shipping and aquaculture (Carlton 1985; Gollasch 2002; Nehring and Leuchs 1999), or of natural range expansions (Carlton 1989). Once an alien species has arrived in a new region, further spread can contribute to the influence on the recipient region (Grosholz 2002; Wasson et al. 2001). The accelerated spread (worldwide and local) of non indigenous species is also facilitated by climate change (Stachowicz et al. 2002; Walther et al. 2002). Understanding the dynamics of transport, settlement and invasion of non indigenous species is therefore necessary to assess the long term consequences for marine ecosystems (Occhipinti-Ambrogi 2007). Particularly, the dynamic of an invasion during the initial phase of a successful invader could help to understand the mechanisms which invasion are underlying (see Grosholz 2002; Occhipinti-Ambrogi 2007). In this paper we describe the population dynamics of the invasive Pacific oyster (Crassostrea gigas; Thunberg, 1793) during their initial spread in the East Frisian Wadden Sea area of the North Sea.

The Pacific oyster is one example of a species that was intentionally for (e.g. aquaculture) or unintentionally introduced in many different regions, where it further dispersed by natural means (Andrews 1980; Chew 1990; Ruesink et al. 2005), e.g. North America (Andrews 1979; Quayle 1969), South America (Escapa et al. 2004), South Africa (Robinson et al. 2005), Australia (Ayres 1991; Dix 1991) and Europe: France (Grizel and Héral 1991), The Netherlands (Drinkwaard 1999), Germany (Reise 1998; 
Wehrmann et al. 2000) and England (Eno et al. 1997). An overview on bioinvasion by oysters is found in Ruesink et al. (2005).

In the southern North Sea, the Pacific oyster was deliberately introduced for aquaculture into the Oosterschelde (The Netherlands) in 1965 (Drinkwaard 1999; Reise 1998), the first successful spat falls of the Pacific oyster outside aquaculture plots occurred in 1975 and 1976 (Drinkwaard 1999). After these recruitment events, abundances increased along the southern North Sea coast. In 1983, Bruins (1983) reported the first Pacific oyster findings in the Wadden Sea attached to stones at Texel, and in 1998, Tydeman (1999) discovered Pacific oysters in the Harbour of Eemshaven (at the Dutch-German border). On the East Frisian coast, the first individuals were found in 1998 (Wehrmann et al. 2000).

The spread of the Pacific oyster in the East Frisian Wadden Sea can be traced back to this earlier introduction to the Oosterschelde in The Netherlands (Wehrmann et al. 2000). Former failed attempts of introduction for aquaculture in the East Frisian Wadden Sea (dates and place of Pacific oyster aquaculture attempts: 1974 Neuharlingersiel; 1976/1982 Jade, 1982 Wangerooge, 1987 Norderney (Neudecker 1985; Wehrmann et al. 2000)) have not lead to the establishment of feral oysters in the area. A successful Pacific oysters aquaculture on the German coast is located at the island of Sylt, from where a spread throughout the northern Wadden Sea started 5 years after the introduction in 1986 (Diederich 2005; Nehls et al. 2006; Reise 1998). Although in the northern Wadden Sea attempts of introduction for aquaculture were done before the successful aquaculture at Sylt (see Nehls and Büttger 2007).

Previously, non indigenous bivalves, such as the clam Mya arenaria (Strasser 1999) and the razor clam Ensis americanus (Armonies and Reise 1999), found a niche in the Wadden Sea ecosystem (see also Reise et al. 2005). A high "niche opportunity", that appears to be provided by the Wadden Sea ecosystem raises the receptiveness of a community to invasive species. The "niche opportunity" defines conditions that promote invasions in terms of resources, natural enemies, the physical environment, interactions between these factors, and the manner in which they vary in time and space (Shea and Chesson 2002). The low species richness in the coastal northern European waters and the vacant ecological niches in the North Sea after the last glaciations can facilitate the success of invading species on the German coast (see Reise et al. 2006; Vermeij 1991; Kennedy et al. 2002; Levine and D'Antonio 1999; Levine 2000). Furthermore, as the Wadden Sea is a highly dynamic ecosystem (Reise et al. 2005), where, e.g. sediment rearrangements may produce empty patches, it is very receptive to introduced species (Carlton 1996; Sousa 2001). However, unlike previous invasions by $M$. arenaria and $E$. americanus, the Pacific oysters are more likely to change the habitat structure in the Wadden Sea, affecting blue mussel beds (Mytilus edulis) and their associated organisms.

A remarkable increase in oyster abundance has already been observed in the Dutch and northern German Wadden Sea (Dankers et al. 2004; Diederich et al. 2005; Dankers et al. 2006;), and was postulated to be due to low mortality and high growth rates in settled Pacific oysters during their first 5 years of age (Diederich et al. 2005; Diederich 2006; Reise 1998).

Our study is, to our knowledge, the first one documenting a marine bioinvasion during the first years in which populations of the invasive species about to arise. The beginning spread of the Pacific oyster in the East Frisian Wadden Sea (Wehrmann et al. 2000) provided the opportunity to study the population dynamic of the invader during the initial phase of the invasion. Especially from the east part of the East Frisian Wadden Sea no reports of Pacific oyster occurrences were known before our study. Our investigations concentrated on population growth and mortality of the Pacific oyster. For this purpose, densities and size-frequencies of Pacific oysters were investigated on tidal flats of the East Frisian Wadden Sea (Germany).

\section{Methods}

Study site

The study area covered the entire Wadden Sea of Lower Saxony (Germany) between the Ems estuary in the west and the Elbe estuary in the east $\left(6^{\circ} 40^{\prime} \mathrm{E}\right.$ to $8^{\circ} 40^{\prime} \mathrm{E}$ and $54^{\circ} 60^{\prime} \mathrm{N}$ to $53^{\circ} 20^{\prime} \mathrm{N}$ ). The area is characterised by muddy to sandy tidal flats with a semidiurnal tide cycle and a tidal range of 2.3-3.9 m. In the area between the mainland and the barrier islands, 15 blue mussel (Mytilus edulis) beds were chosen for the investigation (Fig. 1), based on information provided by the National Park administration about the occurrence of blue mussel beds, logistic considerations and similar conditions (such as flooding time, location in lower intertidal, similar high (approximately 0 $1.2 \mathrm{~m}$ above low tide). The mussel beds were also selected to assure an even distribution of study sites throughout the entire area. The investigation was carried out on blue mussel beds, as they provide the main hard substrate available for Pacific oysters settling in the Wadden Sea. Other hard substrates are shell beds, harbour walls, groins, dikes and other artificial substrates.

The areas of the mussel beds were mapped using a global-positioning system (GPS). To assess the spatial extent of a mussel bed, all areas occupied by mussels not more than $25 \mathrm{~m}$ apart were included. These criteria were adapted from the blue mussel monitoring carried out by the National Park administration (see also Herlyn 2005). The 
Fig. 1 Locations of the 15 investigated mussel beds on the tidal flats of the Lower Saxony Wadden Sea, Germany. Shaded (light grey) areas indicate tidal flats

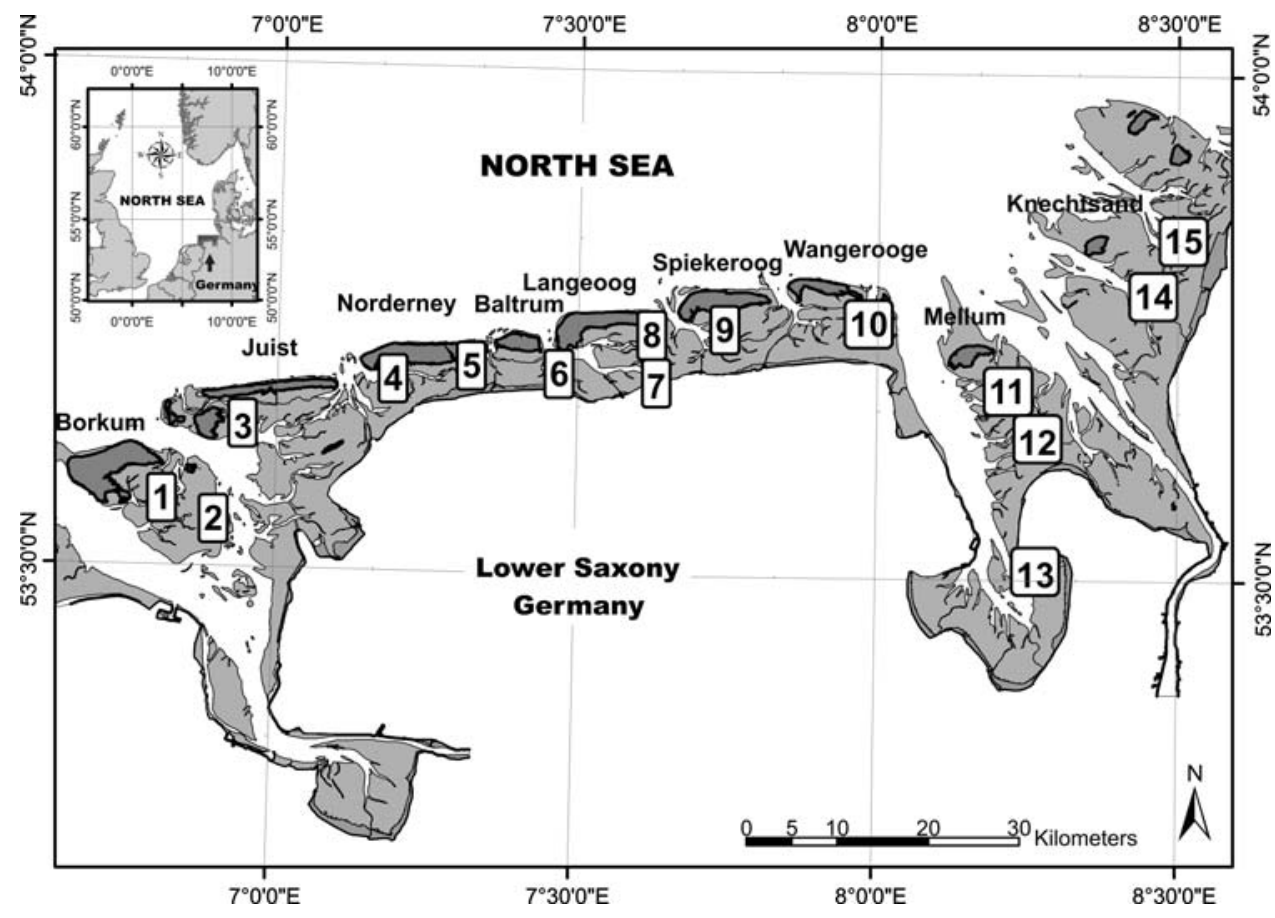

mussels and Pacific oysters, the randomly distributed sampling grids included the range of microhabitat topography of a mussel bed. The sampling sites were located by using a GPS (Garmin GPS 72) and were marked with bamboo sticks for relocation in the following years. At each sampling site, oyster density was determined within a $1 \mathrm{~m}^{2}$ quadrate and the size of oysters measured as the largest distance from the hinge, using a calliper to the nearest $\mathrm{mm}$. Measurements were done in the field, and all oysters were left on the sampling site, to avoid a change in the natural composition. From 2004 onward, the quadrate size was reduced to $0.25 \mathrm{~m}^{2}$ for those mussel beds showing a high abundance of Pacific oysters. Oyster densities are given as mean abundance \pm standard error (SE) of the 100 sampling sites per mussel bed for the comparison of the abundance increase between years. For the data analysis, the abundance of the mussel beds (each mussel bed $n=100$ ) was used, but in Fig. 2 abundance data are plotted as Box and Whisker-Plot to better reflect the patchiness on a mussel bed. Variations were high as a mussel bed comprises areas occupied by mussels and sandy or muddy open space in between. The maxima are representing oyster patches on a mussel bed.

Data analysis

Abundance distributions of the Pacific oyster in the entire study area

The annual population increase is calculated from mean oyster abundances of all investigated mussel beds. Data were tested for normality using the Kolmogorov-Smirnov less occasional occurrence of bivalve shells, single Blue 

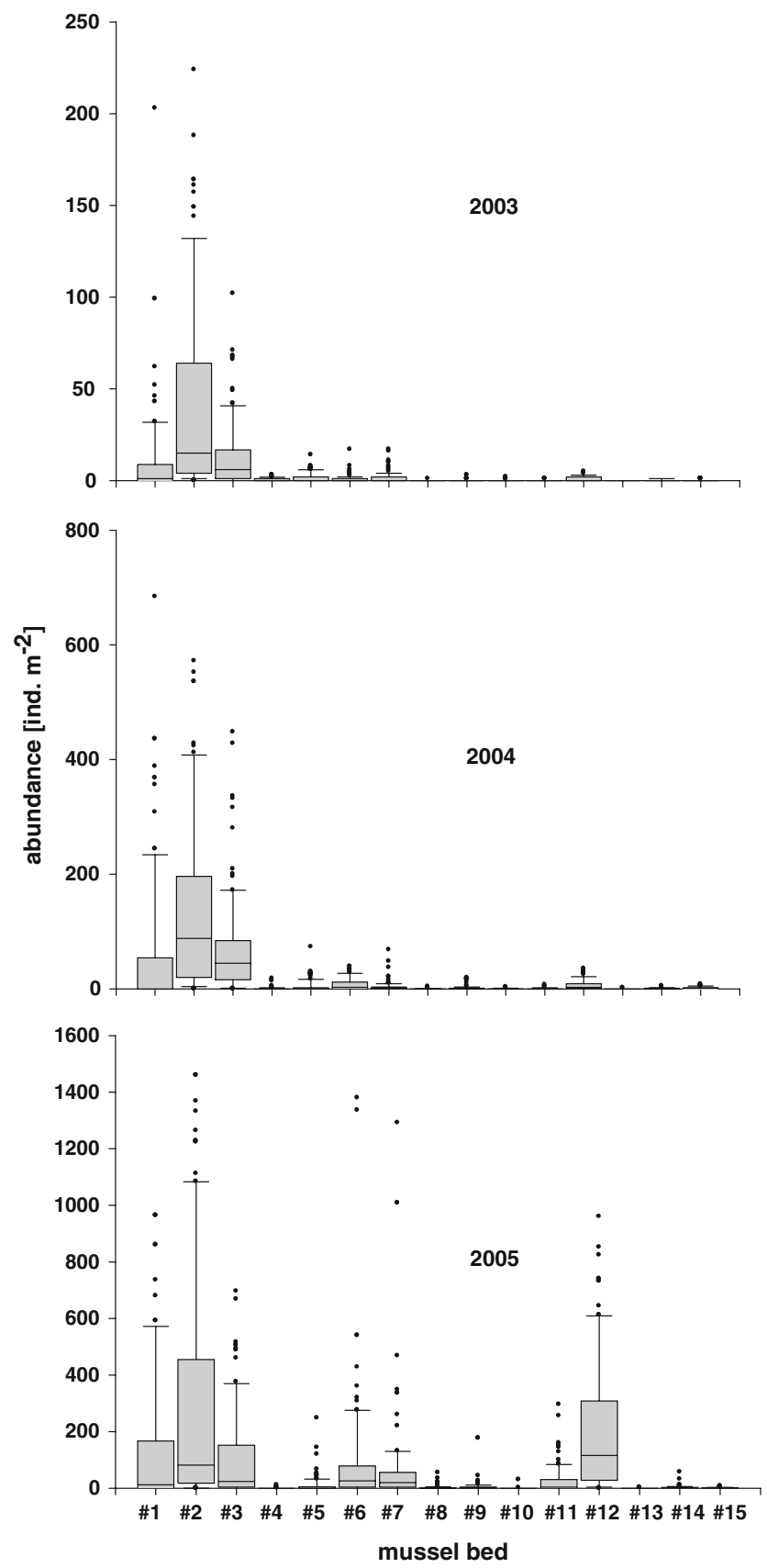

Fig. 2 Abundance of the Pacific oyster on all investigated mussel beds (for the location see Fig. 1) in the years 2003, 2004 and 2005. Box plots show median (horizontal line within box), 25th and 75th percentiles (box) and 10th and 90th percentile (whiskers); circles indicate all outlier. For the comparison of abundances during 1 year each Box and Whisker-Plot has different scaled axis of abscissa

test, but as assumptions for ANOVA could not be met, nonparametric statistics applied. To test for inter annual changes in abundance we used the Wilcoxon signed-ranks test or the Friedman test. To compare the Pacific oyster populations between the 15 mussel beds for each year separately, the Kruskal-Wallis- $H$ test was used. As post hoc analysis, the Nemenyi-test was used. Effects were considered to be statistically significant if the $P$ value was $\leq 0.05$. The year to year increase was calculated for the mean of all mussel beds.

\section{Length frequency distribution, population growth} and mortality

Length frequency distributions were determined for all investigated mussel beds, but are presented only for the exemplary mussel beds: \#2, \#3, \#6 and \#12 (5 mm size classes, annual). For a better comparison of the length frequency distribution between the mussel beds, the data are shown as relative abundances. The length frequency distribution data were fitted to the "von Bertalanffy growth function" (VBGF) with the program FiSAT II. This was done for all mussel beds, except for the mussel beds \#4, \#10, \#13 and \#15 where calculations were impossible due to low population size. For the calculation of the growth constant $(K)$ of the VBGF, the Shepherd's method from the FiSAT II was used. The length $L_{\infty}$ is given from FiSAT II and represents the largest accepted length present in the population. The possible maximum length of the Pacific oyster was not reached during the studied period of early invasion, therefore we used $L_{\infty}$ given by FiSAT II. The mortality rate $Z y_{y e a r}{ }^{-1}$ for the entire duration of the investigation was calculated by a fit of the size converted catch curve with FiSAT II. Additionally, the year to year mortality was calculated on the exemplary mussel beds with a high oyster abundance (\#2 and \#3) by direct determination over the cohort size with the formula:

$-Z=\ln \left(\frac{N_{1}}{N_{0}}\right)$

where $Z$ is the mortality, In the natural Logarithm, $N_{l}$ the cohort size at time $T_{1}$ and $N_{0}$ the cohort size at $T_{0}$. These calculations do not include the early mortality directly after settlement due to the mode of data collection. The abundance and length of the $N_{0}$ generation was determined approximately 0.5 year after settlement, so the first generation is further noted as $N_{1}$ generation. The cohorts, size and mean length for the calculation of mortality and mean shell growth was determined with the Bhattacharya's method using FiSAT II.

The mean shell growth in the second and third year was calculated from the differences between the mean lengths of single cohorts from the mussel bed \#3 and \#12.

\section{Results}

Abundance and distribution of Pacific oyster in the East Frisian Wadden Sea

In the course of the three study years (2003-2005), an increasing spread of Pacific oyster was recorded from the 
west towards the east. The quantitative surveys on 15 mussel beds throughout the study area demonstrated this population increase (Fig. 2). The abundances (ind. $\mathrm{m}^{-2}$ ) of the Pacific oysters differed significantly on the mussel beds over the years (Table 1). In 2003, three groups with similar oyster abundance each and a significant distinction between the groups $(P \leq 0.05)$ were distinguished after the comparison of all mussel beds (group 1 with mussel bed $\# 1-\# 3$; group 2 with \#4-\#7 and group 3 with \#8-\#15; see Fig. 2, year 2003). These groups represented mussel beds with similar oyster densities descending in densities from the west (high) to the east (low), but in 2004 and 2005 this spatial distribution exist not any more. This and the similarity between mussel beds in each year is visible in Fig. 2, especially the maxima showing the similarity because they indicate that on the patchy mussel beds some areas had a similar high oyster density.

In 2003, the largest oyster populations were found in the west, south of the islands Borkum and Juist, with mean abundances of 11.11 ind. $\mathrm{m}^{-2}$ (mussel bed \#1) up to 42.44 ind. $\mathrm{m}^{-2}$ (mussel bed \#2) and a maximum on a sample plot of 224 ind. $\mathrm{m}^{-2}$ (mussel bed \#2). Mean abundances were lower towards the eastern parts and did not exceed 1.59 ind. $\mathrm{m}^{-2}$, with no Pacific oysters found in the Jade Bay (mussel bed \#13).

In 2004, a significant increase of the Pacific oyster abundances occurred on 13 of the 15 mussel beds (Table 1), and the first oysters were found in the Jade Bay.
Oyster abundances increased 5.3 times in the whole study area from 2003 to 2004. The oyster densities of the mussel beds \#5, \#6, \#7 and \#12 were significantly higher (Table 1), with a four to eight times increase in comparison to the adjacent tidal basins. The highest mean abundance of 136.24 ind. $\mathrm{m}^{-2}$ was found on mussel bed \#2. The maximum abundance on a sample plot recorded in 2004 was also in the western region on mussel bed \#1 with 684 ind. $\mathrm{m}^{-2}$.

By 2005, the Pacific oyster population had increased further, with an overall increase of 9 times over 2004 for the whole study area. The increase was highest on mussel beds \#6, \#7 and \#12, where abundances reached the level of the mussel beds in the west. The largest population was still on mussel bed \#2 with a mean abundance of 302.04 ind. $\mathrm{m}^{-2}$ and a maximum oyster number found on a sample plot of 1,460 ind. $\mathrm{m}^{-2}$. On mussel bed \#4 the abundance of the Pacific oyster decreased significantly, because this and also mussel bed \#15 were almost destroyed during the winter 2004-2005.

\section{Length-frequency-distributions}

Oysters found ranged in size from 1 to $234 \mathrm{~mm}$. On the basis of length-frequency-distributions (Fig. 3), one new cohort was identified by FiSAT II in every year. The $N_{1}$ cohort of the year 2003 (recruits of autumn 2002 which were already approximate 0.5 year old) could be followed

Table 1 Spatial extent of all investigated mussel beds, with mean abundance \pm SE and maximum abundance of Pacific oyster in 2003 , 2004 and 2005

\begin{tabular}{|c|c|c|c|c|c|}
\hline \multirow[t]{2}{*}{ Mussel bed } & \multirow{2}{*}{$\begin{array}{l}\text { Mussel bed area } \\
2003 \text { [ha] }\end{array}$} & \multicolumn{3}{|c|}{ Crassostrea gigas (ind. $/ \mathrm{m}^{2}$ ) } & \multirow{2}{*}{$\begin{array}{l}\text { Significant change } \\
\text { of the abundance }\end{array}$} \\
\hline & & $\begin{array}{l}2003 \\
\text { Mean } \pm \text { SE }\end{array}$ & $\begin{array}{l}2004 \\
\text { Mean } \pm \text { SE }\end{array}$ & $\begin{array}{l}2005 \\
\text { Mean } \pm \text { SE }\end{array}$ & \\
\hline$\# 1$ & 3.13 & $11.11 \pm 2.65$ & $55.40 \pm 12.05$ & $150.56 \pm 25.71$ & $\mathrm{a}, \mathrm{b}, \mathrm{c}$ \\
\hline$\# 2$ & 22.83 & $42.44 \pm 5.34$ & $136.24 \pm 14.90$ & $302.04 \pm 40.96$ & $a, b, c$ \\
\hline \#3 & 37.09 & $13.32 \pm 1.92$ & $70.92 \pm 8.92$ & $107.97 \pm 16.12$ & $a, b, c$ \\
\hline \#4 & 7.67 & $0.41 \pm 0.08$ & $0.83 \pm 0.27$ & $0.23 \pm 0.12$ & $\mathrm{a}, \mathrm{c}$ \\
\hline \#5 & 18.98 & $1.47 \pm 0.25$ & $4.22 \pm 1.02$ & $10.73 \pm 3.24$ & $\mathrm{a}, \mathrm{b}, \mathrm{c}$ \\
\hline \#6 & 11.09 & $0.96 \pm 0.21$ & $7.99 \pm 1.05$ & $93.80 \pm 21.16$ & $\mathrm{a}, \mathrm{b}, \mathrm{c}$ \\
\hline \#7 & 28.54 & $1.59 \pm 0.31$ & $3.91 \pm 0.94$ & $77.36 \pm 19.94$ & $\mathrm{a}, \mathrm{b}, \mathrm{c}$ \\
\hline \#8 & 48.85 & $0.01 \pm 0.01$ & $0.18 \pm 0.18$ & $2.42 \pm 0.74$ & $\mathrm{a}, \mathrm{b}, \mathrm{c}$ \\
\hline \#9 & 28.69 & $0.12 \pm 0.05$ & $1.66 \pm 1.66$ & $6.47 \pm 2.53$ & $\mathrm{a}, \mathrm{b}, \mathrm{c}$ \\
\hline \#10 & 6.77 & $0.09 \pm 0.03$ & $0.2 \pm 0.05$ & $0.62 \pm 0.42$ & $a, b, c$ \\
\hline \#11 & 14.21 & $0.04 \pm 0.02$ & $0.46 \pm 0.11$ & $27.85 \pm 5.20$ & $a, b, c$ \\
\hline \#12 & 6.51 & $0.91 \pm 0.12$ & $6.67 \pm 0.85$ & $205.56 \pm 23.61$ & $a, b, c$ \\
\hline \#13 & 14.15 & 0 & $0.03 \pm 0.02$ & $0.06 \pm 0.04$ & \\
\hline \#14 & 5.91 & $0.13 \pm 0.03$ & $0.67 \pm 0.11$ & $2.58 \pm 0.67$ & $a, b, c$ \\
\hline \#15 & 12.29 & $0.09 \pm 0.03$ & $1.42 \pm 0.18$ & $1.24 \pm 0.16$ & $a, b$ \\
\hline
\end{tabular}

Significant increase is shown $(P \leq 0.05)$ : a = Friedman-test (all 3 years of investigation), $\mathrm{b}$ and $\mathrm{c}=$ Wilcoxon-test $(\mathrm{b}=2003-2004)$ $(c=2004-2005)$. At mussel bed \#4 the change between 2004 and 2005 was a significant decrease 
up to the $N_{3}$ generation. The $N_{1}$ and $N_{2}$ cohorts were visible as bimodal peaks in 2004 and 2005.

For the second and the third year, the annual shell growth was calculated from the Length-Frequency-Distribution of mussel bed \#3, \#6 and \#12, for example. At mussel bed \#3, the mean growth of the Pacific oyster was $44 \mathrm{~mm} \mathrm{year}^{-1}$ in the second year of growth, and $27 \mathrm{~mm} \mathrm{year}^{-1}$ in the third year. For mussel bed \#12, the Pacific oyster grew $29 \mathrm{~mm}$ year $^{-1}$ on average in their second year and $32 \mathrm{~mm} \mathrm{year}^{-1}$ in the third year. For calculations on mussel bed \#6 only the last two years could be used, with a growth of $46 \mathrm{~mm}$ year $^{-1}$ for the second year and $40 \mathrm{~mm}$ year ${ }^{-1}$ for the third year.

To describe the population growth and mortality over 3 years, the VBGF were fitted to the data sets and the growth constant $(K)$ with the maximal expected length $\left(L_{\infty}\right)$, and the mortality $(Z)$ was calculated. The growth constant of the VBGF varied in the range from $K=0.300$ year $^{-1}$ at mussel bed \#3 with $L_{\infty}=186.90 \mathrm{~mm}$ and $K=0.990$ year $^{-1}$ at mussel bed \#11 with $L_{\infty}=129.15 \mathrm{~mm}$ (Table 2).

For mussel beds \#2 and \#3, the mortality $(Z)$ was calculated for the $2003 \mathrm{~N}_{1}$ cohort. Between a 0.5 and 1.5 year, the mortality on mussel bed \#2 was $Z=0.03$ year $^{-1}$ and on \#3 $Z=0.13$ year $^{-1}$, after one more year the mortality on mussel bed \#2 was $Z=0.82$ year $^{-1}$ and on \#3 $Z=1.61$ year $^{-1}$. The mortality rate $Z$ year $^{-1}$ calculated with FiSAT II for the entire duration of the investigation was in the range of 1.19-3.16 year ${ }^{-1}$ (Table 2) and therefore many times higher than the calculations for the first and second year were showing.

\section{Discussion}

Investigations describing the population dynamics of a beginning marine bioinvasion are rarely available in the literature. Most studies describe the current state of a bioinvasion (e.g. Grizel and Héral 1991; Mann and Harding 2000; Streftaris et al. 2005) or the change over several years (e.g. Diederich et al. 2005; Escapa et al. 2004; Herkül et al. 2006; Oliveira et al. 2006). The first investigation on Pacific oyster appearance outside of the 1986 established oyster farm at the island Sylt situated in the northern part of the German Wadden Sea were done by Reise (1998), he described the oyster occurrence around the island in 1993 and 1996, while the first findings of the Pacific oyster in the
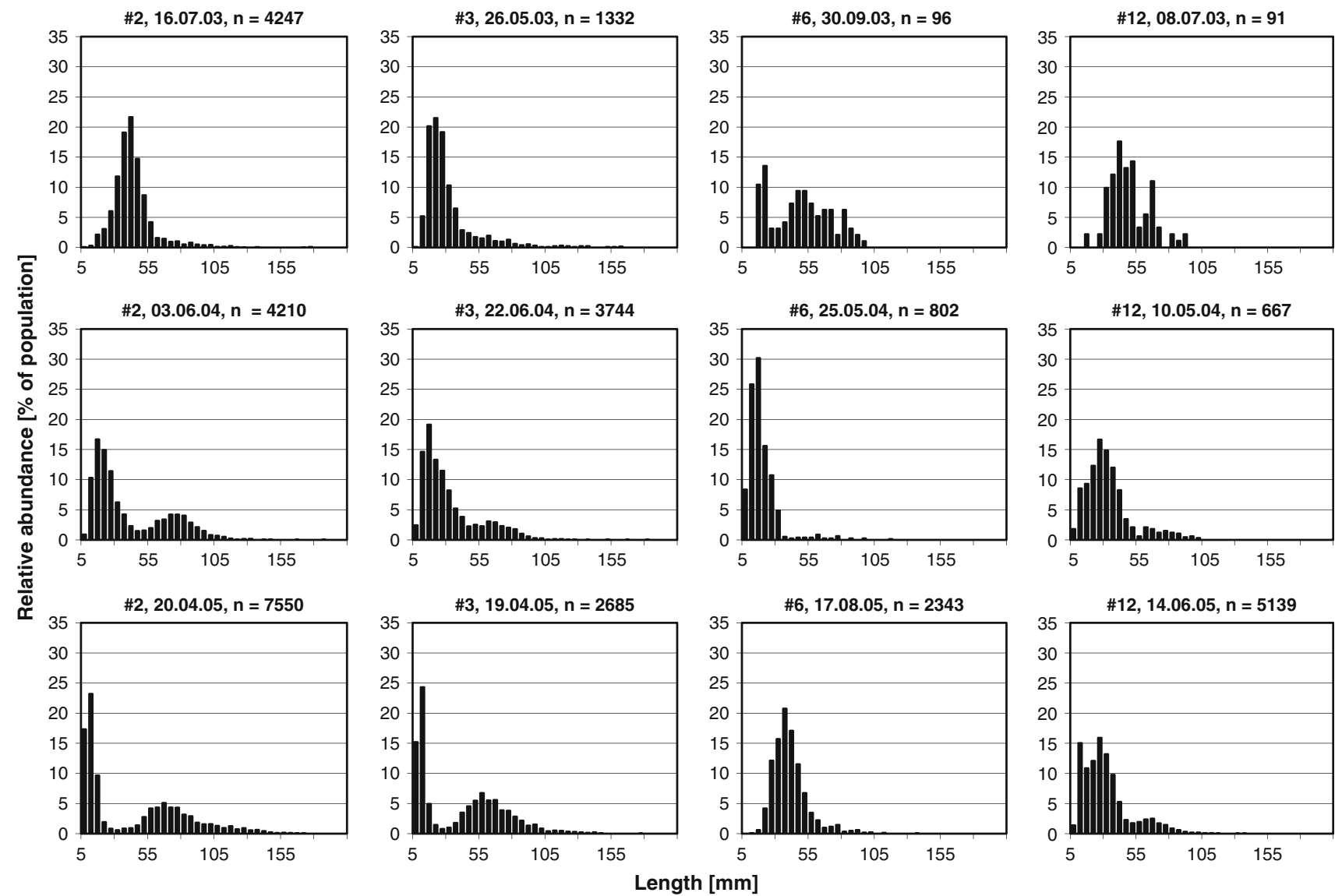

Fig. 3 Annual length-frequency distribution $(L F D)$ from Pacific oysters of three selected mussel beds (mussel bed \#2, \#3 and \#12) in 2003, 2004 and 2005 
Table $2 \mathrm{~L}_{\infty}$, growth constant $(K)$ and mortality $(\mathrm{Z})$ of the Pacific Oyster populations calculated for the 3 years of investigation

\begin{tabular}{lcll}
\hline Mussel bed & $L_{\infty}(\mathrm{mm})$ & $\mathrm{K} \mathrm{year}^{-1}$ & $\mathrm{Z}$ year \\
\hline$\# 1$ & 207.90 & 0.440 & 1.55 \\
$\# 2$ & 192.15 & 0.390 & 1.41 \\
$\# 3$ & 186.90 & 0.300 & 1.19 \\
$\# 5$ & 144.90 & 0.410 & 1.20 \\
$\# 6$ & 139.65 & 0.580 & 1.67 \\
$\# 7$ & 160.65 & 0.910 & 2.92 \\
$\# 8$ & 139.65 & 0.320 & 0.89 \\
$\# 9$ & 139.65 & 0.510 & 1.44 \\
$\# 11$ & 129.15 & 0.990 & 3.16 \\
$\# 12$ & 139.65 & 0.580 & 2.14 \\
$\# 14$ & 92.40 & 0.670 & 1.53 \\
\hline
\end{tabular}

East Frisian Wadden Sea were done in 1998 by Wehrmann et al. (2000). These findings in the East Frisian Wadden Sea provided the opportunity for this case study to examine the beginning of a bioinvasion and the beginning spread of a marine invasive species on a large scale of about $120 \mathrm{~km}$ of coastline.

The invasion of the Pacific oyster, starting from the aquacultures in the Oosterschelde, is only partly described for the Dutch Wadden Sea (Dankers et al. 2004; Drinkwaard 1999; Tydeman 1999) and the East Frisian Wadden Sea (Wehrmann et al. 2000), while more is known about the oyster population in the northern German Wadden Sea (Diederich et al. 2005; Diederich 2006). Both invasions differ in the origin of the non-indigenous oyster. In the East Friesian Wadden Sea the invasion of Pacific oyster is a spread by natural means with a distant introduction source (Wehrmann et al. 2000), whereas the invasion in the northern German Wadden Sea is enforced by a continuous input of larvae from a local oyster farm (Diederich et al. 2005). It is important to differentiate both invasion events to understand the causes for their successful bioinvasion.

The successful introduction of an invasive species is divided into four successive phases: arrival, settlement, expansion and persistence (Mollison 1986; Reise et al. 2006). For the invasion of the Pacific oyster in the East Frisian Wadden Sea we could detect the first three phases of introduction. The arrival of the Pacific oyster in the western part of the east Frisian Wadden Sea was postulated to have been taken place between 1994 and 1996 (Wehrmann et al. 2000), and the first discovery in the eastern part of the east Frisian Wadden Sea was in 2001 (Herlyn and Millat 2004). The first small populations in the west were found in 1998/1999 (Wehrmann et al. 2000) and in the east in 2002/2003 (Herlyn and Millat 2004; and this study). With the spat fall from 2002, the population in the west started the expansion phase with a significant increase in abundance (Table 1), and the same was observed in 2005 in the east. Hence, the oyster had an establishment phase of 4-6 years. For the oysters which were introduced in 1986 in the List tidal basin at the island Sylt, the first significant spatfall was in 1991 (Diederich et al. 2005; Reise 1998), 5 years after introduction. This is in agreement with the expected establishment phase of 4-6 years for a Pacific oyster population in the southern North Sea. After the establishment phase, only one or two more generations are necessary for a rapid increase of the population. Our investigations started with the beginning expansion phase of the invasive oyster in the East Frisian Wadden Sea. The population increase differed between mussel beds. We found that the population increase was faster in the vicinity of the accepted local source populations than further away, e.g. mussel bed \#6, \#7 had a higher increase than the nearby beds \#5 and \#8 located in the adjacent tidal basins and mussel bed \#12 in comparison to nearby bed \#11 (see Fig. 2). Similar effects were described by Diederich et al. (2005) for the List tidal basin at the island of Sylt. This local increase we found, with a successful recruitment in every investigated year indicates that the spreading of the oyster takes place in a restricted area around the source population. A possible cause for the local increase could be the hold off storm events resulting in lacks of water currents, therefore without storm events larvae are retained in a restricted area around the source population (see also Dunstan and Bax 2007).

Key factors for the spread are the wind conditions together with a successful spat fall, as shown for the invasive mussel Mytilus galloprovincialis in South Africa (McQuaid and Phillips 2000). Our study period fell into years with low mean wind speed during the spawning period (data Deutscher Wetter Dienst DWD). A natural wide spread dispersal eastwards of approximately $150 \mathrm{~km}$ per year of a benthos species with a free swimming larval phase of around 20-30 days is a theoretically expectable value under special weather conditions at the southern North Sea coast (Armonies 2001; Wehrmann et al. 2000). The spread is attributed to the eastward residual current of approximately $0.1 \mathrm{~m} \mathrm{~s}^{-1}$ due to special wind conditions (constantly over a 3-4 week period) existing in coastal waters of the southern North Sea (Armonies 2001; Wehrmann et al. 2000). Wide dispersal of larvae only happens during such wind conditions, as was the supposed case for the spread of the oyster in the years 1994-1996 (Wehrmann et al. 2000). In these years, the oyster recruited on a coast line of approximately $50 \mathrm{~km}$ between the islands of Borkum and Baltrum on the East Frisian coast, coming from the western Netherlands as indicated by the comparison of oyster abundances in 2003, where we found decreasing abundances towards the east (see Fig. 2). In 
1994 and 1995 the water temperature was significantly higher during the oyster larvae period from July to October than average, coinciding with a significant oyster recruitment in 1994 at the island of Sylt (Diederich et al. 2005), and also the wind was significantly stronger than average in the period between 1990 and 2005, with a mean south western wind direction (Deutscher Wetter Dienst (DWD)), both factors had a positive influence for an eastward wide spread of oyster larvae. Additional to dispersal by current, we are not able to exclude the possibility that the oyster was further transported within the Wadden Sea by human activities such as ship transport, whether on the hull or in ballast water (Carlton 1999). Chew (1990) described the introduction of the Pacific oyster to New Zealand by the arrival of adult oysters on hulls of ships with a subsequent settlement, prosper and reproduction of their spawn. One hint for additional dispersal of the oyster by ships comes from the massive spat fall in 1999 in the harbour of Eemshaven (The Netherlands) (Tydeman 1999).

Most studies on the population dynamics of marine invertebrates are carried out for non invasive populations, for example the bivalves Aequipecten opercularis (L.) from the western English Channel (Heilmayer et al. 2004), Donax serra from Namibian sandy beaches (Laudien et al. 2003) and from the Wadden Sea Cerastoderma edule (Ramón 2003) and Mytilus edulis (Munch-Petersen and Kristensen 2001). Only the studies of Diederich (Diederich et al. 2005; Diederich 2006) give the opportunity for a detailed comparison of the population dynamic of the invasive Pacific oyster in the East Frisian Wadden Sea.

The population growth rate (the constant $(K)$ from the von Bertalanffy growth function (VBGF)) we calculated for the East Frisian Pacific oyster population was threefold higher than that calculated by Diederich (2006) of the North Frisian population.

In comparison to the above mentioned non invasive populations, the population growth constant of the Pacific oyster from the Wadden Sea (range $K=0.3-0.99$ year $^{-1}$ ) is in the range of native natural occurrence populations: $K=0.604$ year $^{-1}$ for the population of Aequipecten opercularis (L.) from the western English Channel (Heilmayer et al. 2004), $K=0.274$ year $^{-1}$ for the population of Donax serra from Namibian sandy beaches (Laudien et al. 2003) and $K=0.404$ year $^{-1}$ for the Cerastoderma edule population from the Wadden Sea (Ramón 2003) and $K=0.243-0.902$ year $^{-1}$ for the Mytilus edulis population (Munch-Petersen and Kristensen 2001). Thus, the Pacific oyster population in the Wadden Sea can be described as a population which can be viable.

The formation of Pacific oyster populations in different parts of the world show how successful the oyster is as an invader. In Chile, the first invasive oysters were found 5 years after introduction in 1982, then from 1995 there was incipient colonization with 2 oysters $\mathrm{m}^{-2}$; settlement increased explosively since 1998 with a density of up to 120 recruits $\mathrm{m}^{-2}$ (Orensanz et al. 2002). On South African shores, the Pacific oyster had a relatively long establishment phase of 51 years. It was introduced in the 1950s and wild oyster populations were first recorded in 2001 (Robinson et al. 2005). Even though the time was very long between the oyster introductions and the first wild population, the oyster was able to persist and adapt to the new environment where it could build up a stable population in the end. The establishment phase we found, similar to the invasion in Chile and that point that the oyster can build viable populations even after a very long time after introductions like in South Africa together with the considerable increase of the Pacific oyster abundance indicates the possibility that an self sustaining populations com into begin in the Wadden Sea.

The success of the Pacific oyster invasion in the East Frisian Wadden Sea was further accelerated by the low mortality of 0.5-2 years old juveniles. For the young oyster population of the north Frisian Wadden Sea, Reise (1998) also reported a low mortality, in spite of a foregoing severe winter. Calculated (with FiSAT II) over the 3 years of our investigation, total mortality was $Z=1.19-3.16$ year $^{-1}$ and thus in the range of other mussel populations in the Wadden Sea, e.g. Cerastoderma edule with $Z=0.52-3.03$ year $^{-1}$ (Ramón 2003) and Mytilus edulis with a mean annual mortality of $Z=0.84$ year $^{-1}$ (Munch-Petersen and Kristensen 2001). In contrast to the higher mortality of $M$. edulis during the first years, the mortality of the oyster population we found increased with the years. Also Diederich (2006) found low mortality rate for the first three months post-settlement $(M=0.004$ day $\left.^{-1}\right)$ and during the first winter $\left(M=0.005\right.$ day $\left.^{-1}\right)$ of the Pacific oyster during experiments in the List tidal basin near the island Sylt. The low mortality we found can indicate a lack of oyster predators during the first period of the bioinvasion. Main predators like the shore crabs Carcinus maenas and the starfish Asterias rubens prefer the native blue mussel over the non native Pacific oyster (Diederich 2005). After several years, predators could learn to feed on the non native oysters and the mortality in the first year would increase.

The analysis of the length-frequency-distribution showed a new cohort in every investigated year on each mussel bed. A successful recruitment was also observed for the years 2001-2003 for the northern area of the Wadden Sea of Germany (Diederich et al. 2005). The successful recruitments can be related to warm summers with aboveaverage temperatures of more than $18^{\circ} \mathrm{C}$ in July/August (Diederich et al. 2005). Therefore, the spread of the oyster in the Wadden Sea seems to have benefited from temperature rise with climate change, which is also affecting 
native bivalves in the Wadden Sea (Beukema and Dekker 2005).

The individual mean growth we calculated for the oysters of the East Frisian population was similar to the growth of the oysters in the northern part of the Wadden Sea, where Diederich (2006) described the individual growth rate as somewhat lower compared to other areas and only slightly lower than in the native habitat (Japan and Korea). The high individual growth rate can protect the oyster against predation and can function as protection against the environment. On a mussel bed which accumulated a lot of sediment we observed oysters growing with a long and thin shell, whereas on another mussel bed, which was exposed more against waves, the oysters produced thicker shells.

The now widespread occurrence and high abundance of the invasive Pacific oyster in the East Frisian Wadden Sea suggests likely effects of this introduced bivalve for the Wadden Sea ecosystem, e.g. a substitution of blue mussel beds with oyster reefs or a change to mixed beds of Pacific oysters and Blue mussels. In many other regions, introduced molluscs are now the most abundant infaunal or epifaunal species (Carlton 1999); e.g. Mytilus galloprovincialis is the dominating mussel throughout the Western Cape region of South Africa, where they largely displaced the native mussel Aulacomya ater (Griffith et al. 1992). Considering the current population growth and low mortality, our investigation allows the prediction that the Pacific oyster presently has the potential to become one of the most abundant epifaunal bivalves in the Wadden Sea.

Acknowledgments The research carried out for this manuscript has been funded by the "Niedersächsische Wattenmeerstiftung" and is further a partial fulfilment for a PhD. Thanks are expressed to Gerald Millat, Ulrike Schleier and Jürgen Laudien for their helpful and friendly support with field work and data analysis. We are also grateful to Torsten Janßen and many trainees for their help with field work and to Katharina Deutz for her help with the data handling. Further we thank the three anonymous reviewers for their valuable commends on the manuscript.

\section{References}

Andrews JD (1979) Scenario for introduction of Crassostrea gigas to the Atlantic coast of North America. In: Mann R (ed) Exotic species in Mariculture. The MIT Press, Cambridge, pp 225-231

Andrews JD (1980) A review of introductions of exotic oysters and biological planning for new importations. Mar Fish Rev 42:1-11

Armonies W (2001) What an introduced species can tell us about the spatial extension of benthic populations. Mar Ecol Prog Ser 209:289-294

Armonies W, Reise K (1999) On the population development of the introduced razor clam Ensis americanus near the island of Sylt (North Sea). Helgol Mar Res 52:291-300

Ayres P (1991) Introduced Pacific oysters in Australia. In: Sutherland J, Osman R (eds) The Ecology of Crassostrea gigas in Australia, New Zealand, France and Washington State. Maryland Sea Grant College, College Park, pp 3-7
Beukema JJ, Dekker R (2005) Decline of recruitment success in cockles and other bivalves in the Wadden Sea: possible role of climate change, predation on postlarvae and fisheries. Mar Ecol Prog Ser 287:149-167

Bruins RWB (1983) Crassostrea gigas (Thunberg, 1783) op Texel. Corresp-blad Ned Malac Ver 215:1436-1438

Carlton JT (1985) Transoceanic and interoceanic dispersal of coastal marine organisms: the biology of ballast water. Oceanogr Mar Biol Ann Rev 23:313-371

Carlton JT (1989) Man's role in changing the face of the ocean: biological invasions and implications for conservation of nearshore environments. Conserv Biol 3:265-273

Carlton JT (1996) Pattern, process, and prediction in marine invasion ecology. Biol Conserv 78:97-106

Carlton JT (1999) Molluscan invasions in marine and estuarine communities. Malacologia 41:439-454

Chew KK (1990) Global bivalve shellfish introductions. World Aquacult 21:9-22

Dankers N, Dijkman EM, de Jong M, de Kort G, Meijboom A (2004) De verspreiding en uitbreiding van de Japanse oester in de Nederlandse Waddenzee. Wageningen, Alterra, Alterra-rapport 909

Dankers NMJA, Meijboom A, De Jong ML, Dijkman E, Cremer J, Fey F, Smaal A, Craeymeersch J, Brummelhuis E, Steenbergen J, Baars D (2006) De ontwikkeling van de Japanse Oester in Nederland (Waddenzee en Oosterschelde). Wageningen IMARES Rapport C040/06, 57 pp

Diederich S (2005) Invasion of Pacific oysters (Crassostrea gigas) in the Wadden Sea: Competitive advantage over native mussels. Dissertation, Christian-Albrechts-Universität, Kiel, $154 \mathrm{pp}$

Diederich S (2006) High survival and growth rates of introduced Pacific oysters may cause restrictions on habitat use by native mussels in the Wadden Sea. J Exp Mar Biol Ecol 328:211-227

Diederich S, Nehls G, van Beusekom JEE, Reise K (2005) Introduced Pacific oysters (Crassostrea gigas) in the northern Wadden Sea: invasion accelerated by warm summers? Helgol Mar Res 59:97-106

Dix TG (1991) The Pacific oyster, Crassostrea gigas, in Australia. In: Menzel W (ed) Estuarine and marine bivalve mollusk culture. CRC Press, Boca Raton, pp 315-318

Drinkwaard AC (1999) Introductions and developments of oysters in the North Sea area: a review. Helgol Mar Res 52:301-308

Dunstan PK, Bax NJ (2007) How far can marine species go? Influence of population biology and larval movement on future range limits. Mar Ecol Prog Ser 344:15-28

Eno NC, Clark RA, Sanderson WG (1997) Non-native marine species in British waters: a review and directory. Joint Nature Conservation Committee, JNCC Petersborough, ISBN 186107442 5, pp 136

Escapa M, Isacch JP, Daleo P, Alberti J, Iribarne O, Borges M, Santos EPD, Gagliardini DA, Lasta M (2004) The distribution and ecological effects of the introduced Pacific oyster Crassostrea gigas (Thunberg, 1793) in northern Patagonia. J Shellfish Res 23:765-772

Gollasch S (2002) The importance of ship hull fouling as a vector of species introductions into the North Sea. Biofouling 18:105-121

Grosholz E (2002) Ecological and evolutionary consequences of coastal invasions. Trends Ecol Evol 17(1):22-27

Griffith CL, Kockey PAR, m Shurink C, Le Roux PJ (1992) Marine invasive aliens on South African shores: implications for community structure and trophic functioning. South Afr J Mar Sci 12:713-722

Grizel H, Héral M (1991) Introduction into France of the Japanese oyster (Crassostrea gigas). J Cons Int Explor Mer 47:399-403

Heilmayer O, Brey T, Storch D, Mackensen A, Arntz WE (2004) Population dynamics and metabolism of Aequipecten 
opercularis (L.) from the western English Channel (Roscoff, France). J Sea Res 52(1):33-44

Herkül K, Kotta J, Kotta I (2006) Distribution and population characteristics of the alien talitrid amphipod Orchestia cavimana in relation to environmental conditions in the Northeastern Baltic Sea. Helgol Mar Res 60(2):121-126

Herlyn M (2005) Quantitative assessment of intertidal blue mussel (Mytilus edulis L.) stocks: combined methods of remote sensing, field investigation and sampling. J Sea Res 53(4):243-253

Herlyn M, Millat G (2004) Wissenschaftliche Begleituntersuchungen zur Aufbauphase des Miesmuschelmanagements im Nationalpark "Niedersächsisches Wattenmeer". Abschlußbericht der Niedersächsischen Wattenmeerstiftung, Wilhelmshaven, Germany (unpublished)

Kennedy A, Naeem S, Howe KM, Knops JMH, Tilman D, Reich P (2002) Biodiversity as a barrier to ecological invasion. Nature 417:636-638

Laudien J, Brey T, Arntz WE (2003) Population structure, growth and production of the Surf clam Donax serra (Bivalvia, Donacidae) on two Namibian sandy beaches. Est Coast Shelf Sci 58:105-115

Levine JM (2000) Plant diversity and biological invasions: relating local process to community pattern. Science $288: 852-854$

Levine JM, D'Antonio CM (1999) Elton revisited: a review of evidence linking diversity and invasibility. Oikos 87:15-26

Mann R, Harding JM (2000) Invasion of the North American Atlantic coast by a large predatory Asian mollusc. Biol Inv 2:7-22

McQuaid CD, Phillips TE (2000) Limited wind-driven dispersal of intertidal mussel larvae: in situ evidence from the plankton and the spread of the invasive species Mytilus galloprovincialis in South Africa. Mar Ecol Prog Ser 201:211-220

Mollison D (1986) Modelling biological invasion: change, explanation, prediction. Philos Trans R Soc Lond Ser B 314:675-693

Munch-Petersen S, Kristensen PS (2001) On the dynamics of the stocks of blue mussels (Mytilus edulis L.) in the DanishWadden Sea. Hydrobiologia 465:31-43

Nehls G, Diederich S, Thieltges DW, Strasser M (2006) Wadden Sea mussel beds invaded by oysters and slipper limpets-competition or climate control? Helgol Mar Res 60:135-143

Nehls G, Büttger H (2007) Spread of the Pacific Oyster in the Wadden Sea. Causes and consequences of a successful invasion. Interreg IIIB-HARBASINS Project, http://cwss.www.de/news/ symposia/oyster2007/Pacific-oyster-report-April-2007.pdf, pp 54

Nehring S, Leuchs H (1999): Neozoa (Makrozoobenthos) an der deutschen Nordseeküste-Eine Übersicht. Bundesanstalt für Gewässerkunde, Koblenz, Bereicht BfG-1200, pp 131

Neudecker T (1985). Untersuchungen zur Reifung, Geschlechtsumwandlung und künstlichen Vermehrung der Pazifischen Auster Crassostrea gigas in deutschen Gewässern. Dissertation, Instituts für Küsten- und Binnenfischerei, Universität Hamburg, pp 212

Occhipinti-Ambrogi A (2007) Global change and marine communities: alien species and climate change: marine bioinvasions: a collection of reviews. Mar Poll Bull 55(7-9):342-352

Oliveira MD, Takeda AM, Barros LF, Barbosa DS, Resende EK (2006) Invasion by Limnoperna fortunei (Dunker, 1857) (Bivalvia, Mytilidae) of the Pantanal wetland, Brazil. Biol Inv 8:97104
Orensanz JM, Schwindt E, Pastorino G, Bortolus A, Casas G, Darrigran G, Elias R, Gappa JJL, Obenat S, Pascual M, Penchaszadeh P, Piriz ML, Scarabino F, Spivak ED, Vallarino EA (2002) No longer the Pristine Confines of the World Ocean: a survey of exotic marine species in the Southwestern Atlantic. Biol Inv 4(1):115-143

Quayle DB (1969) Pacific oyster culture in British Columbia. Ottawa: Bulletin of the Fisheries Board of Canada, Bulletin 169, the Queen's Printer Ottawa Canada, pp 192

Ramón M (2003) Population dynamics and secondary production of the cockle Cerastoderma edule (L.) in a backbarrier tidal flat of the Wadden Sea. Sci Mar 67:429-443

Reise K (1998) Pacific oyster invade mussel beds in the European Wadden Sea. Senckenb Marit 28:167-175

Reise K, Dankers N, Essink K (2005) Introduced species. In: Essink K, Dettmann C, Farke H, Laursen K, Lüerßen G, Marencic H, Wiersinga W (eds) Wadden Sea quality status report 2004. Common Wadden Sea Secretariat, Wilhelmshaven, Germany, pp $155-161$

Reise K, Olenin S, Thieltges DW (2006) Are aliens threatening European aquatic coastal ecosystems? Helgol Mar Res 60:77-83

Robinson TB, Griffiths CL, Tonin A, Bloomer P, Hare MP (2005) Naturalized populations of oysters, Crassostrea gigas along the South African coast: distribution, abundance and population structure. J Sea Res 24:443-450

Ruesink JL, Lenihan HS, Trimble AC, Heiman KW, Micheli F, Byers JE, Kay MC (2005) Introduction of non-native oysters: ecosystem effects and restoration implications. Annu Rev Ecol Evol Syst 36:643-689

Shea K, Chesson P (2002) Community ecology theory as a framework for biological invasions. Trends Ecol Evol 17:170-176

Sousa WP (2001) Natural disturbance and the dynamics of marine benthic communities. In: Bertness MD, Gaines SD, Hay ME (eds) Marine community ecology. Sinauer Associates, Inc., Sunderland, pp 85-130

Stachowicz JJ, Terwin JR, Whitlatch RB, Osman RW (2002) Linking climate change and biological invasions: ocean warming facilitates nonindigenous species invasions. Proc Natl Acad Sci USA 99(24):15497-15500

Strasser M (1999) Mya arenaria — an ancient invader of the North Sea coast. Helgol Mar Res 52(3-4):309-324

Streftaris N, Zenetos A, Papathanassiou P (2005) Globalisation in marine ecosystems: the story of non-indigenous marine species across European seas. Oceanogr Mar Biol Ann Rev 43:419-453

Tydeman P (1999) Japanse oesters in de Eemshaven. Het Zeepaard 59:58-64

Vermeij GJ (1991) When biotas meet: understanding biotic interchange. Science 253:1099-1104

Walther G-R, Post E, Convey P, Menzel A, Parmesan C, Beebee TJC, Fromentin JM, Hoegh-Guldberg O, Bairlein F (2002) Ecological responses to recent climate change. Nature 416(6879):389-395

Wasson K, Zabin CJ, Bedinger L, Diaz CM, Pearse JS (2001) Biological invasions of estuaries without international shipping: the importance of intraregional transport. Biol Conserv 102(2):143-153

Wehrmann A, Herlyn M, Bungenstock F, Hertweck G, Millat G (2000) The distribution gap is closed-first record of naturally settled Pacific oysters Crassostrea gigas in the East Frisian Wadden Sea, North Sea. Senckenb Marit 30:153-160 